\title{
ENTREPRENEURIAL MARKETING DIMENSIONS AND MARKET PERFORMANCE OF SMALL AND MEDIUM-SCALED ENTERPRISES IN NIGER DELTA, NIGERIA
}

\author{
Panama, Amos Ejiroghene \\ Department of Petroleum Marketing and Business Studies \\ Petroleum Training Institute, Effurun Nigeria
}

\author{
Adeola A. Ayodele \\ Department of Marketing, Nnamdi Azikiwe University Awka, Nigeria.
}

\begin{abstract}
Although small and medium enterprises provide diverse employment opportunities and economic growth in the Nigerian economy, entrepreneurial marketing has received little attention in the Niger Delta region of Nigeria in spite of challenges faced by them. The study examined the entrepreneurial marketing dimensions and market performance of small and medium scale enterprises in Delta State. A sample of 245 respondents comprises of owners or managers of SME's in Warri/Effurun Metropolis were selected for study. Convenience sampling techniques was used to select the sample after the area has been subdivided into zone with quota sampling methods. A survey research design was used to collect data from respondents through the use of questionnaire. Hypothesized relationships between the variables of study were tested using multiple regressions. Findings reveal that all the entrepreneurial marketing dimensions of pro-activeness, opportunity-focused, innovation-oriented, customer intensity, resource leveraging and value creation have significant positive relationship with market performance while risk making have a negative relationship. It is therefore recommended that owners and managers of SME's should be pro-active, aggressive and innovative in design of strategies towards enhancing market performance in their organization.
\end{abstract}

KEYWORDS: entrepreneurial marketing, market performance, small and medium-scaled enterprises, Nigeria, Niger Delta.

\section{INTRODUCTION}

Marketing and entrepreneurship have been examined to have a significant interrelationship, which means that they influence one another's effect on performance (Mugambi \& Karugu, 2017). For the last 25 years, entrepreneurship and marketing are two well-established scientific fields, which are central in business studies (Hills \& Hultman, 2013). According to Janet \& Ngugi (2014), Since the mid-1980s a steady stream of research has examined the marketing/entrepreneurship interface in small and medium-sized enterprises (SMEs) and much of that work has concentrated on issues surrounding the implementation of marketing in entrepreneurial companies (Kurtz, (2010). The term Entrepreneurial Marketing (EM) has come to describe the marketing activities of small and new ventures. EM represents an exploration of ways in which entrepreneurial attitudes and behaviors can be applied to the development of marketing strategy and tactics (Krohmer, Homburg, \& Workman, 2011).

According to Mari (2014) entrepreneurial marketing is connected to small companies but it is actually relevant both to large and small companies scenarios. A reason why entrepreneurial 
marketing is often related to SMEs is because it is more visible there and also entrepreneurial focus can be challenging to maintain in large enterprises (Collinson \& Shaw 2001). Entrepreneurial marketing was initially associated with small and resource poor firms that were seen unsophisticated. Nowadays, the visionary nature of entrepreneurial marketing has raised awareness. (Mort, Weerawardena \& Liesch, 2008) Therefore, further studies are needed to describe the visionary nature of entrepreneurial marketing that has been estimated to increase its importance in future. SMEs were chosen as target group since the elements of entrepreneurial marketing are more clearly visible and therefore can be better recognized and analyzed.

However, it was estimated that between 45 and 60 percent of the urban labour force work for small private enterprises in Lagos, Nigeria (Nwaka, 2005 as cited by Oyelola, Ajiboshin \& Raimi, 2013). Another study suggests that entrepreneurship has been beneficial because the Nigerian private sector comprising of small and medium enterprises provides diverse employment opportunities for 50 percent of the country's population and 50 percent of its industrial output (Ariyo, 2005). It is becoming evident that marketing is actually fundamentally different and more successful in SMEs than in large companies with sophisticated marketing practices. The main reason suggested for this is that marketing implementation can be more important to success than planning and strategy (Mari, 2014). Entrepreneurial marketing (EM) has emerged as a marketing practice recommended for firms operating in highly dynamic environments with the focus of an entrepreneurial, innovative and opportunity driven approaches (Morrish, Miles \& Deacon, 2010; Fiore, Niehm, Hurst, Son \& Sadair, 2013).

With stiff competition in the SMEs market and wide range of brokage models working in SMEs, consumers now have wide choice of products/services to contend with. It is therefore critical that SMEs firm have a good marketing strategy to enhance its performance in the industry (Gottchchalg \& Zollo, 2007). Stokes (2000), noted that many SMEs have major problems in the field of marketing such as having small range of customers, financial constraints and little innovation among others. Murigu (2005), opined that SMEs operate in a very turbulent environment of increased risk and diminishing ability to forecast. While Nwaizugbo \& Anukam (2014) noted that entrepreneurial marketing seems to thrive in a highly fluctuating environment as experienced in Nigeria and most often before any formal marketing planning is concluded, new condition would have arisen to render the plan ineffective. This also relates to assertion of Pitsamam et al (2015) which reflects that marketers recognize a need to be flexible in the environment where customers' preferences and technology are constantly shifting. In that light, it's quite pertinent to examine the entrepreneurial marketing dimensions with a view to sorting out the specific strategies that will enable SMEs cope with ever changing marketing environment.

In the same vein, Laniyan Ogbauna \& Oduguwa (2007), opines that although research on SMEs marketing has increased in recent years, existing findings have not been reflected in the marketing practices amongst SMEs in Nigeria, they reiterated that large organizational models applied to small firms setting have been criticized in the literature and there is a need for further research to identify how marketing is practiced within the small and medium enterprise sector in Nigeria. Olaniye and Eromafuru (2016) also noted that entrepreneurial marketing has received little attention in spite of varieties of challenges faced by SMEs in Niger Delta region of Nigeria. This assertion buttresses the report of a survey conducted by NBS/SMEDAN in 2013, which shows that the number of medium enterprises has drop from 33 in 2010 to nil in 2013 which is quite worrisome. Thus, the lack of robust and comprehensive theoretical framework that investigates 
the nexus between entrepreneurial dimension and its influence in marketing performance of SMEs in a typical developing country context like Nigeria is a case in point. Therefore, this study aims at investigating empirically the effect of entrepreneurial marketing dimensions on the market performance of small and medium-scaled enterprises in Delta state, Nigeria. This study is divided into introduction, literature review, materials and methods, analysis, discussion of findings, conclusion and recommendations.

\section{REVIEW OF RELATED LITERATURE}

\section{Entrepreneurial Marketing}

The unstable business environment forces companies to use non-standard approaches of business development and thus traditional patterns of marketing have to be adjusted for the companies of the distant levels of the resources. It is a well-known fact that Entrepreneurial Marketing works more effectively when resources are limited, with which small and micro enterprises have to operate (Becherer \& Maurer, 1997). Thus, Entrepreneurial marketing represents an exploration of ways in which entrepreneurial attitudes and behaviors can be applied to the development of marketing strategy and tactics (Janet \& Ngugi, 2014). To understand entrepreneurial marketing, it is imperative to first establish the meaning of terms "Marketing" and "Entrepreneurship". The American Marketing Association offers the following formal definition: Marketing is the activity, set of institutions, and processes for creating, communicating, delivering, and exchanging offerings that have value for customers, clients, partners, and society at large. Coping with these exchange processes calls for a considerable amount of work and skill (Kotler \& Keller, 2012). Entrepreneurship on the other hand, is any Self-employment of any sort; the activity that involves identifying opportunities within the economic system; the creation of new organizations; the willingness and ability of an individual to seek out investment opportunities in an environment and be able to establish and run an enterprise successfully based on the identifiable opportunities. In Olannye and Eromafuru (2016) the concept of entrepreneurial marketing describe the values, skills and behaviours of entrepreneur in addressing their problems and finding business opportunities, it represents a different approach to envisaging the business itself, its relationship with the market place and the role of marketing function within the firm or as a strategic entrepreneurial posture or behaviour in marketing which is represented by an individual/organization (Sabrina, 2010).

\section{Dimensions of Entrepreneurial Marketing}

\section{Pro-Activeness}

In Mehran, \& Morteza (2014), Bateman \& Crant (1993) argue that proactivity is a personal behavioural construct that exhibits a relatively stable tendency to effect environmental change. Frese \& Fay (2001) bring this further in proposing that proactivity will have a positive impact on individual as well as organizational performance. Proactivity, in a working environment context, can be defined as a continuous organizational process that aims to anticipate, improve and evaluate occupational health and safety practices (Andersen etal., 2010).

Mehran \& Morteza (2014), asserted that pro-activeness reflects entrepreneurial willingness to dominate competitors through a combination of proactive and aggressive moves, e.g. introducing new products or services ahead of competition and acting in anticipation of future demand to create change and shape the environment. Moreover, having a proactive orientation involves discovering 
and satisfying the latent, unarticulated needs of customers through collecting customer-and competitor-based information. Proactiveness is concerned with implementation of something new, doing what is necessary to anticipate and act upon an entrepreneurial opportunity.

\section{Opportunity Focus}

Comparing traditional marketing with entrepreneurial marketing, the latter is more opportunitydriven. There are two crucial marketing actions, as acknowledges and occupation that can bring success for small enterprises. There is a need to choose the "right" opportunity that determines success for firms (Becherer, Haynes \& Helms, 2008). Take a right action at the right time might bring successfulness for firms. Being forward looking as a key point of opportunity focus for entrepreneurs means serve unsatisfied needs and capture new opportunities before their competitors. In this case, innovation and creativeness might help to move forward companies in two steps forward than competitors (Kilenthong et al., 2010).

Recognition and pursuit of opportunity are marketing actions critical to SME success. Market potential is generally evaluated by degree of fit relative to the capabilities and resources of the firm. It is the ability of the firm to select the right opportunity that determines success (Becherer et al., 2008).

Although opportunity can arise randomly, entrepreneurial marketers are known for proactively searching for new opportunities. Being forward looking and having the will to become pioneers makes entrepreneurial firms able to serve unsatisfied needs and capture emerging opportunities before their competitors can. Innovation and creativity are crucial tools that help entrepreneurial firms to turn opportunities into realities (Kilenthong et al., 2010).

\section{Calculated Risk Taking}

According to Nwaizugbo and Anukam (2014), risk-taking based on experience over the years is consistent with entrepreneurial marketing. The power of risk taking, including willing to use substantial resources for exploiting of opportunities with using business strategies based on the results, may be very uncertain (Morris et al., 2004). Firms that have adopted entrepreneurial marketing processes take calculated, rational, measured risks. Firms that have adopted entrepreneurial marketing processes are not gamblers but risk accepters who understand that innovation in the current social, technological, and economic environments is inherently uncertain and requires rational betting on long shots. One method for managing risk is to work in alliance with other parties, which these firms believe will both provide complimentary capabilities and help shift the risks to other parties (Miles \& Darroch, 2004).

\section{Innovativeness}

Becherer et al., (2012), innovation-oriented marketing actions allow the firm to concentrate on ideas that lead to new markets, products or processes. The degree to which a successful organization emphasizes innovation in its marketing actions can range from the highly innovative new market creator to the incremental market builder. The market creator must break with past solutions to offer the customer a radically different value while the incremental innovator builds on existing customer relations and market knowledge. SMEs may choose to focus on innovative means of marketing since the firm may not have the resources to meet or maintain industry standards (Carson \& Gilmore, 2000). 


\section{Customer Intensity}

The dimension of customer intensity builds on what is often viewed as a central driving force of marketing in the organization: a customer -centric orientation employing innovative approaches to create, build, and sustain customer relationships. Many studies suggest successful organizations are those that place a greater emphasis on customer intensity. However, it has also been suggested that extreme customer orientations might inhibit the breakthrough of innovations that create markets and disrupt equilibrium, since these radical changes are out in front of customers (Becherer et al., 2008). Customer orientation has its roots in early services marketing literature in which the importance of customer-focused employees was a tangible sign of quality for the firm and its services. Since then, the concept of customer orientation within firms has been investigated by a number of authors and researchers; indeed, some authors view customer orientation as the 'pillar of marketing' (Jones \&Rowley, 2011).

\section{Resource Leveraging}

One of the key challenges of marketing in new ventures is scarcity of financial and personnel resources. This scarcity demands a strict monitoring of marketing costs, and restricts the range and intensity of marketing activities a new venture is able to pursue. Entrepreneurs can either alleviate this problem by trying to acquire additional resources, such as venture capital or bank loans, or by trying to achieve a maximum effect of these scarce resources. Findings on this topic can be categorized in two groups: strategies and tactics for reducing the amount of resources that must be spent for particular marketing activities (let others pay): and strategies and tactics that require only few resources, yet have a high impact in the marketplace. Strategies and tactics for reducing the amount of resources spent for particular marketing activities include the free- riding strategy as well as the strategy of forming alliances with other organizations. The second group of findings focuses on strategies and tactics that require only few resources yet promise to produce a high impact in the marketplace. These strategies/tactics include the adoption of a niching strategy, a gradual step by step development of marketing activities, and low-cost guerrilla tactics in marketing (Gruber, 2004).

At its most basic level, leveraging means more work with less. Marketers must develop a capacity for resource leveraging. The ability to recognize an under-utilized resource, to see how a resource could be used in a non-conventional way, or to convince those that control a resource to let the marketer use it, requires insight, experience, and skill (Morris et al., 2004).

\section{Value Creation}

In Gliga (2016), both the transactional and relational approach to marketing view value creation to be the epitome and the end goal of interaction in the marketplace. In EM, customer intensity is combined with a focus on innovation and thus "the focal point of EM is innovative value creation, on the assumption that value creation is a prerequisite for transactions and relationships" (Morris et al., 2002, p. 8). Furthermore, given the high level of customer closeness and intensity, entrepreneurs are better positioned to develop value propositions based on points of value that really matter to customers.

\section{Market Performance}

Another perspective of the study is market performance. The marketing performance of a firm can be evaluated in different ways: according to the book "Marketing metrics" 50+ metrics every executive should master". There are 9 main categories of marketing metrics; margins and profits, 
product and portfolio management; customer profitability; sales force and channel management; pricing strategy, promotion, advertising media and web metric, marketing and finance and share of hearts, minds and markets (Olanny \& Eromafuru 2016). Business Success (market performance) measurement for small and medium scale enterprises can be evaluated from a number of perspectives on various dimensions: Create Customer Satisfaction, Create Positive Reputation, Profitability, Sales Growth, Income for Owner, Increase Customer Base, Position for Long-Term Prosperity, Adding Good Employees, and Operates Well with/without Owner (Becherer, Helms, and McDonald, 2012).

According to Dixion et al (1990), as cited in Mohd (2011), performance measurements in the literature until the 1980 largely concentrated on financial indicators such as profit, return on investment, sales per employee and productivity. Commencing from the 1980's onward, less tangible and non financial measures have been extensively employed in line with new management system such as Supply Chain Management (SCM) just in time delivery (JIT) and total quality management (TQM). Intangibles measures include communication, learning, trust, Saad and Patel (2006) stakeholders satisfaction, competition position, Simon et al (2005), quality of product and throughput rate (Abu Kasin et al., 1989). However, Saifi (2016) identify market performance measures to include, customer conversion rates, sales revenue, cost per lead, organic search traffic, social media engagement and average customer value which are but financial and non-financial measures.

\section{The Concept of Small and Medium Scale Enterprises (SME's)}

Small and medium enterprises play vital role in the economic growth and development of many developed and developing countries. In short, Nigeria as a country is benefiting immensely from this development as the country has realized the value of small business. Appropriate definition of SME's has been an issue as there are a lot of different definition of the concept in extant literature.According to literature, the definitions vary in different economics but the underlying concept is the same. Ayyagari et al (2003), Buckley (1989) contends that the "definition of small and medium scale enterprises vary according to context, author and countries. In country such as USA, Britain and Canada, small scale business is defined in terms of annual turnover and the number of paid employees Ekpeyong and Nyang (1992). SME's can also be defined in the context of the size of a SME's or organization in relation to the number of the employees working with that organization or the local amount of its assets and capital levels. Merimo, Monral Perez and Sanchezmarin (2005).

The Central Bank of Nigeria defines small and medium enterprise in Nigeria according to asset base and number of staff employed. The criteria are an asset base equal or less than N5 million and a staff strength equal or less than 100 employees. CBN (2011). While small and medium enterprises development agency of Nigeria SMEDAN (2013) defines EME's as follows:

Small Enterprises: Those that employ between 10 and 40 employees and having a capital base from N5 million to N50 million and medium enterprises as any enterprises that employs from 50 - 199 employees and having a capital base from N50 million to N500 million.

\section{Theoretical Foundation}

This study is anchored upon the resource-based theory. The resource-based view (RBV) emphasizes the firm's resources as the fundamental determinants of competitive advantage and performance. It adopts two assumptions in analyzing sources of competitive advantage (Peteraf \& 
Bergen, 2003). First, this model assumes that firms within an industry (or within a strategic group) may be heterogeneous with respect to the bundle of resources that they control. Second, it assumes that resource heterogeneity may persist over time because the resources used to implement firms' strategies are not perfectly mobile across firms (i.e., some of the resources cannot be traded in factor markets and are difficult to accumulate and imitate). Resource heterogeneity (or uniqueness) is considered a necessary condition for a resource bundle to contribute to a competitive advantage. The argument goes "If all firms in a market have the same stock of resources, no strategy is available to one firm that would not also be available to all other firms in the market" (Peteraf, \& Bergen, 2003). In the resource-based view (RBV) of the firm, a firm's performance is affected by firm-specific resources and capabilities. This implies that, in the RBV, resources are allocated heterogeneously (unevenly) within an industry. Organizations therefore must be aware of their strengths and weaknesses, as they have to develop strategies on how to outperform competitors with the given resources bundles and capabilities. The study of this nature will appraise the entrepreneurial marketing dimensions which forms part of the resources that entrepreneurs use in enhancing market performance.

\section{Fig. 1 Proposed Research Schema}

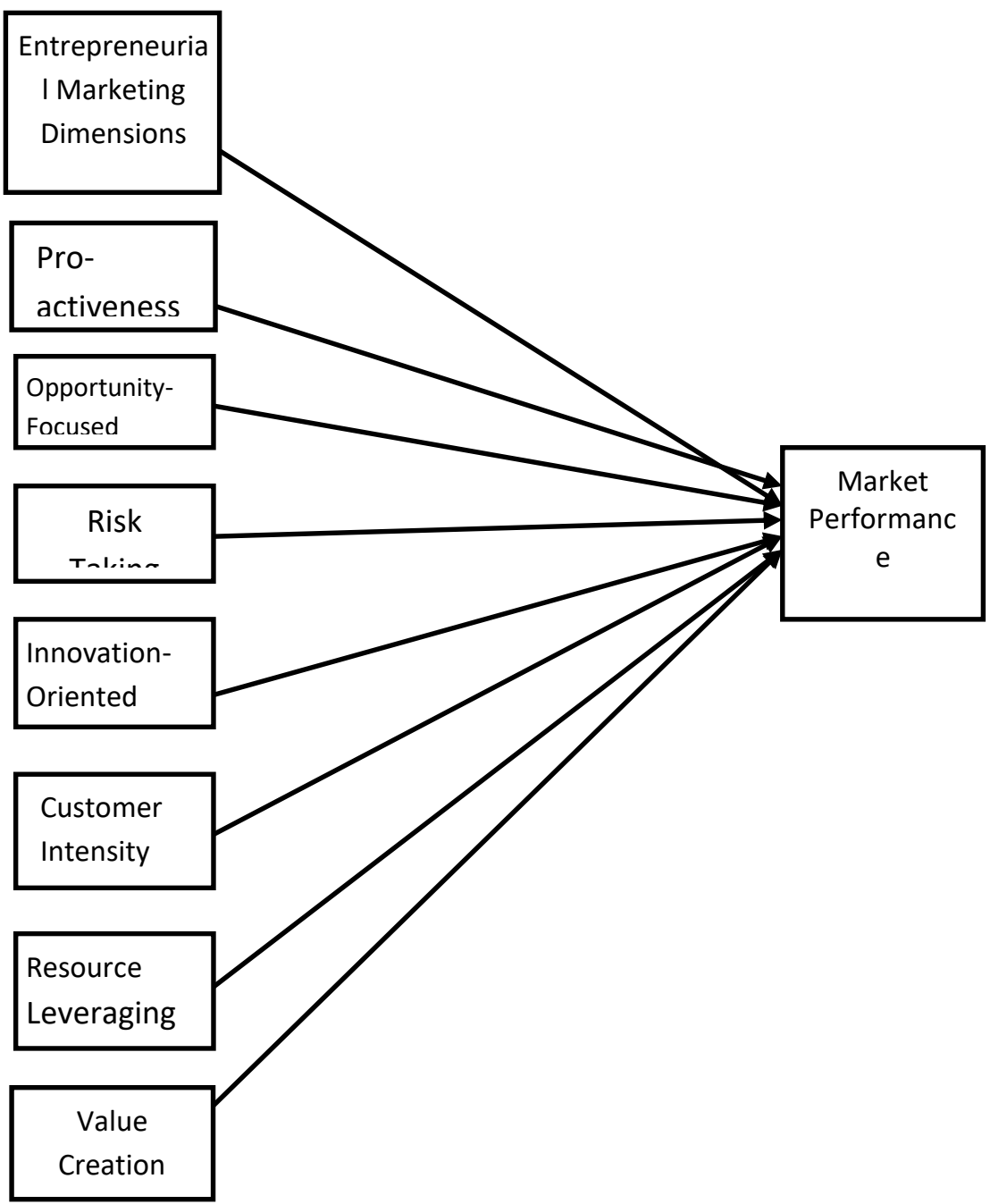

Source: Author's Conceptualization 


\section{Hypotheses Development}

H1: Entrepreneurial proactiveness is positively and significantly associated with market performance of SMEs.

$\mathrm{H} 2$ : $\quad$ Entrepreneurial Opportunity-Focused has a positive relationship with market performance of SMEs in Delta State.

H3: Entrepreneurial risk taking is positively associated with market performance of SMEs in Delta State.

H4: Entrepreneurial Innovativeness is positively associated with market performance of SMEs in Delta State.

H5: Entrepreneurial customer intensity is positively associated with market performance of SMEs in Delta State.

H6: Entrepreneurial resource leveraging has significant relationship with market performance of SMEs in Delta State.

H7: Entrepreneurial value creation is positively associated with market performance of of SMEs in Delta State.

\section{MATERIALS AND METHODS}

The study was conducted using quantitative research design involving surveys. Quantitative research places heavy emphasis on using formalized questions and predetermined response options in questionnaires administered to large numbers of respondents (Hair et al., 2016). Data were primarily collected through questionnaire with received responses analyzed in numerical form in order test hypotheses and predict relationships. Convenience sampling technique was used for the study as it was not quite possible to obtain the registered list of all the SMEs in Warri as the approach was also applied in similar studies of this nature (Mohammed, 2011; Nwaizugbo \& Anukam, 2014).

The study employed a convenience sample of managers and owners of enterprises in Warri/Effurun metropolis consisting of areas within Warri Township and Effurun environs. These areas which comprises of Igbudu/Essi Layout, Ogunu/Federal Government College, Okere in Warri metropolis and Airport Road, Refinery Road and Ekpan in Effurun which are the commercial nerve centre of the towns and also the commercial hub of Delta state Nigeria. This is also related to similar studies that were conducted using a state (Blackson \& Chery 2005; Blackson et al., 2006 as cited in Mohammed, 2011).

In order to determine the sample size for the study, a pilot survey was conducted with questionnaire to determine those entrepreneurs of SME's that will participate in the study. It was randomly done in enterprises established in Warri and Effurun environs. 50 copies of the questionnaire were administered and 40 representing $80 \%$ of the respondents affirmed their participation in the study while 10 representing $20 \%$ did not affirm. Using Cochran (1963) formula to determine sample size.

$\mathrm{n}=\frac{\mathrm{z}^{2}(\mathrm{pq})}{\mathrm{e} 2}$

where $\mathrm{n}=$ Required sample size

$\mathrm{z}=$ Standard deviation of the desired confidence interval of $95 \% 1.96$

$\mathrm{p}=$ Probability of positive response 
$\mathrm{z}=$ Probability of negative response

$\mathrm{e}=$ Limit of standard error $50 \%=0.05$

$\mathrm{n}=1.96^{2} \frac{(0.80)(.20)}{0.0025}$

$\mathrm{n}=245.85$

$\mathrm{n}=245$

The research instrument used for this study was questionnaire. The questions used for the survey were designed based on the constructs (entrepreneurial marketing dimensions constraint and market performance). The questionnaire is composed of two section: Section A that measures demographic profile of respondents and section B measured the main constructs of the study comprises of the independent variables such as pro-activeness opportunity focused, risk taking, innovation-oriented, customer intensity, resource leveraging and value creation in multidimensional form while that of the dependent variable, market performance was measured in unidimensional constructs. These constructs were measured in a 5 point likert-scale question using options of "Strongly agree, "Agree" "Undecided" "Disagree and "Strongly disagree."

To validate the Research instrument, face validity was conducted as draft copies of the questionnaires were given to research experts and my supervisors for proper scrutiny and vetting, comments, thereof were used in drafting the final questionnaire. Also, the question items used in measuring entrepreneurial marketing dimension were adapted from Beckerer, et al (2012) in a similar study conducted in England. While the question items that measured market performance construct were adapted from the work of Saifi (2016).

Table 3.1 below show different Cronbach alpha value for the 8 constructs of the scale questionnaire which were all considered sufficiently adequate for the study. The overall value of Cronbach alpha is .793 which indicated there was internal consistency of the variables scaled and that variables construct exhibit strong internal reliability and is above recommended threshold of 0.7 (Nunnally \& Bernstein 1994).

Table 3.1: Reliability of Constructs

\begin{tabular}{|l|l|l|}
\hline Constructs & Variable items & Cronbach's alpha \\
\hline All & 29 & .793 \\
\hline Market Performance & 4 & .848 \\
\hline Proactiveness & 3 & .745 \\
\hline Opportunity-focused & 3 & .749 \\
\hline Risk-taking orientation & 4 & .869 \\
\hline Customer Intensity & 5 & .789 \\
\hline Value Creation & 4 & .756 \\
\hline Innovation Oriented & & .724 \\
\hline Resource Leveraging & 2 & .783 \\
\hline
\end{tabular}

Source: SPSS 23 


\section{ANALYSIS AND RESULT}

In carrying out the study a total of 245 copies of questionnaire were distributed to managers and owners of enterprises selected out of 200 copies were duly filled and returned. This represents a response rate of $88.89 \%$ which is quite acceptable for a research of this nature because the researcher personally administers the questionnaire on drop-off basis which gave respondents ample time to fill before they were collected.

\section{Table 4.8: Descriptive Statistics}

\begin{tabular}{|l|l|l|l|l|l|}
\hline & N & Sum & Mean & Std. Deviation & Variance \\
\hline Proactiveness & 200 & 504.3333 & 3.191983 & .7021293 & .493 \\
\hline Risk-taking Orientation & 200 & 524.2500 & 3.318038 & .6108420 & .373 \\
\hline Customer Intensity & 200 & 534.0000 & 3.379747 & .6160806 & .380 \\
\hline Value Creation & 200 & 534.5000 & 3.382911 & .5814755 & .338 \\
\hline Innovation-Oriented & 200 & 535.7500 & 3.390823 & .6191179 & .383 \\
\hline Opportunity-Focused & 200 & 540.5000 & 3.420886 & .6917902 & .479 \\
\hline Resource Leveraging & 200 & 546.2330 & 3.654618 & .7737811 & .497 \\
\hline
\end{tabular}

Source: SPSS Version 23

The table 4.8 above shows the descriptive statistics of the data collected. The standard deviation and variance are above 0.5 and 0.1 respectively showing that the data collected are adequate for the study of this nature.

\section{Model Specification}

Multiple regression model was used to measure relationship between multi-dimensional constructs of proactiveness, opportunity focused, risk-taking orientation, customer intensity, value creation, innovation oriented, resource leveraging and unidimensional dependent variable market performance.

The research model for the study can be expressed below as follows:

$\mathrm{y}=\mathrm{a}+\mathrm{b}_{1} \mathrm{x}_{1}+\mathrm{b}_{2} \mathrm{x}_{2}+\mathrm{b}_{3} \mathrm{x}_{3}+\mathrm{b}_{4} \mathrm{X}_{4}+\mathrm{b}_{5} \mathrm{x}_{5}+\mathrm{b}_{5} \mathrm{X}_{6}+\mathrm{b}_{7} \mathrm{X}_{7+e}$

where:

$\mathrm{y}=$ Market performance

$\mathrm{a}=$ constant

$\mathrm{b}=$ coefficient

$\mathrm{x}_{1}=$ Proactiveness

$\mathrm{x}_{2}=$ Risk-taking orientation

$\mathrm{x}^{3}=$ customer intensity

$\mathrm{x}^{4}=$ Value creation

$\mathrm{x}^{5}=$ Innovation orientation

$\mathrm{x}_{6}=$ Opportunity-focused

$\mathrm{x}^{7}=$ Resource leveraging

$\mathrm{u}=$ error term

Table 4.9: Model Summary Table

\begin{tabular}{|l|l|l|l|l|}
\hline Model & $\mathbf{R}$ & R Square & Adjusted R Square & $\begin{array}{l}\text { Std. Error of the } \\
\text { Estimate }\end{array}$ \\
\hline 1 & $.888^{\mathrm{a}}$ & .788 & .780 & .2729195 \\
\hline
\end{tabular}

Source: SPSS Version 23 
The table 4.9 shows the model summary of the data. The coefficient correlation of 0.888 shows that there exist a strong and positive correlation between the independent variables, pro-activeness, opportunity-focused, risk taking orientation, customer intensity, value creation, innovationoriented and resource leveraging and dependent variable (Market performance of Small and Medium Enterprises.) Coefficient of determination $\mathrm{R}^{2}$ and correlation coefficient reveals that $\mathrm{R}=.780 ; \mathrm{R}^{2}=.788$, showing that the seven independent variables had a strong relationship. More so, the $\mathrm{R}^{2}$ value of 0.788 shows that $78.8 \%$ of the independent variables are associated with the dependent variable while the rest value of $22.2 \%$ are as a result of other variable not included in the model.

Table 4.10: ANOVA

\begin{tabular}{|l|l|l|l|l|l|l|}
\hline \multicolumn{2}{|l}{} & & & & & \\
\multicolumn{2}{|l}{ Model } & Sum of Squares & df & Mean Square & F & Sig. \\
\hline 1 & Regression & 41.837 & 6 & 6.973 & 93.613 & $.000^{\mathrm{b}}$ \\
\cline { 2 - 8 } & Residual & 11.247 & 151 & .074 & & \\
\cline { 2 - 7 } & Total & 53.084 & 157 & & & \\
\hline
\end{tabular}

Source: SPSS Version 23

Furthermore table 4.10 shows that F-value of 93.613 which is significant at .000 revealed that the measurement model is of good fit and could be used for further analysis.

Table 4.11: Coefficients Table

\begin{tabular}{|c|c|c|c|c|c|c|}
\hline & & Unstal & Coefficients & $\begin{array}{l}\text { Standardized } \\
\text { Coefficients }\end{array}$ & & \\
\hline & & B & Std. Error & Beta & $\mathrm{t}$ & Sig. \\
\hline 1 & (Constant) & .234 & .143 & & 1.642 & .103 \\
\hline & Pro-activeness & .423 & .062 & .434 & 6.852 & .000 \\
\hline & Opportunity-focused & .039 & .053 & .041 & .736 & .463 \\
\hline & Risk-taking Orientation & -.043 & .055 & -.052 & -.787 & .433 \\
\hline & Customer Intensity & .058 & .059 & .061 & .987 & .325 \\
\hline & Value Creation & .186 & .056 & .198 & 3.350 & .001 \\
\hline & Innovation-Orientation & .257 & .061 & .306 & 4.229 & .000 \\
\hline & Resource Leveraging & .441 & .072 & .422 & 1.622 & .000 \\
\hline
\end{tabular}

Source: SPSS Version 23

The regression equation earlier stated is expressed as follows in line with coefficients.

Recall $\mathrm{y}=\mathrm{a}+\mathrm{b}_{1} \mathrm{x}_{1}+\mathrm{b}_{2} \mathrm{x}_{2}+\mathrm{b}_{3} \mathrm{x}_{3}+\mathrm{b}_{4} \mathrm{x}_{4}+\mathrm{b}_{5} \mathrm{x}_{5}+\mathrm{b}_{5} \mathrm{x}_{6}+\mathrm{b}_{7} \mathrm{x}_{7}$

Thus $\mathrm{y}=.234+423 \mathrm{x}_{1}+.039 \mathrm{x}_{2}-.043 \mathrm{x}_{3}+.058 \mathrm{x}_{4}+.186 \mathrm{x}_{5}+257 \mathrm{x}_{6}+.441 \mathrm{x}_{7}+.143$

Where $\mathrm{y}=$ market performance of SMEs

$\mathrm{x}_{1}=$ Pro-activeness

$\mathrm{x}_{2}=$ Opportunity focused

$\mathrm{x}_{3}=$ Risk-taking orientation

$\mathrm{x}_{4}=$ Customer intensity

$\mathrm{X}_{5}=$ Value Creation

$\mathrm{x}_{6}=$ Innovation-orientation

$\mathrm{x}_{7}=$ Resource leveraging 


\section{RESULT AND FINDINGS}

Seven hypotheses were proposed and their result were explained below:

$\mathrm{H}_{1}$ : Entrepreneurial proactiveness is positively and significantly associated with market performance of SMEs in Delta State. The coefficient i.e. B for pro-activeness is .423 which shows that for every unit increase in pro-activeness will result in a 0.43 unit increase in market performance of SME holding other variables constant. The coefficient is significant at .000 with $t$ value of 6.852. Thus it is accepted signifying that entrepreneurial proactiveness is positively and significantly associated with market performance of SMEs.

$\mathrm{H}_{2}$ : Entrepreneurial Opportunity-Focused has a positive relationship with market performance of SMEs in Delta State. The coefficient of this hypothesis is 0.39 showing that for every unit increase in opportunity focused will also result in a 0.41 unit increase in market performance of SME holding other variables constant. Close view of the coefficient shows that it is significant at .463 or .0001 value is .736. Therefore, $\mathrm{H}_{2}$ is accepted signifying that Entrepreneurial OpportunityFocused has a positive relationship with market performance of SMEs.

$\mathrm{H}_{3}$ : Entrepreneurial risk taking is positively associated with market performance of SMEs in Delta State. Similarly, the coefficient of this hypothesis is - .043 measuring that for every unit increase in risk-taking orientation will result in a -052 unit increase in market performance of SME holding other variables constant. The coefficient shows that it is significant at .0433 or .001 at $t$ value of .0787. This $\mathrm{H} 3$ is also accepted.

$\mathrm{H}_{4}$-Entrepreneurial Innovative-orientation is positively associated with market performance of SMEs in Delta State.In the same vein, the coefficient of this hypothesis is .058 also showing that for every unit increase in customer intensity will result in a 0.61 unit increase in market performance holding other variable constant. The coefficient is also significant at .325 at $\mathrm{F}$ value of .987 .

H5 - Entrepreneurial customer intensity is positively associated with market performance of SMEs in Delta State. Further more, the coefficient of this hypothesis is .186 and .198 respectively meaning that for every unit increase in value creation will result in a 198 unit of market performance holding other variables constant. The coefficient is also accepted at T 3.350 and significant level of .0001

H6 - Entrepreneurial resource leveraging has significant relationship with market performance of SMEs in Delta State. Hypothesis on innovative orientation and market performance of SME can also be explained from the coefficient. It has a coefficient of .257 signifying that for every unit in innovation orientation will result in .306 unit increase in market performance of SME. It also shows a $\mathrm{T}$ value of 4.229 which is significant at .000 and is also accepted.

H7 - Entrepreneurial value creation is positively associated with market performance of of SMEs in Delta State. Finally, the coefficient of this hypothesis is .4441 also showing that for every unit increase in resource leveraging will result in a .422 unit in market performance. The coefficient shows a $t$ value of 1.622 and is significant at .000 meaning that the hypothesis is also accepted 


\section{DISCUSSION OF FINDINGS}

Having done the analysis data of the study and hypothesis tested. The finding of the study shows that entrepreneurial pro-activeness is positively and significantly associated with market performance. Entrepreneurial pro-activeness is quite pertinent to organizational success.

It is concerned with constantly doing something new to outperform competitors and satisfying the needs and wants of customers. This corroborates Mehren \& Mortega (2014) that asserted that proactiveness reflects entrepreneurial willingness to dominate competitors through aggressive moves by introducing new products ahead of competitors and acting in anticipation of future demand to create change.

The study also provides empirical support that apart from entrepreneurial proactiveness, other entrepreneurial marketing dimensions such as opportunity focused, risk-taking orientation, customer intensity, value creation and innovation orientation have significant influence on market performance of SME in Delta State. The analysis of data of the study also shows that although the aforementioned entrepreneurial marketing dimensions significantly influence market performance risk-taking orientation have a negative relationship with the dependent variable meaning that owners or managers of SME are less likely to take risk in ensuring market performance of their enterprises. This may be attributed to uncertainties related to this venture and it corroborates with Morris et al 2004 that opined that the power of risk taking including willing to use substantial resources for exploiting of opportunities with using business strategies based on the results may be very uncertain.

\section{CONCLUSION}

This study examines the entrepreneurial marketing dimensions and how they influence market performance of SMEs, Multiple regression models were specified and estimated to evaluate the relationship between seven independents variables of pre-activeness, opportunity focused, risk taking innovation oriented, customer intensity resource leveraging and value creation with the dependent variable market performance. Results or the model reveals that all the independent variables have a positive and significant relationship with market performance except risk-taking that has a negative relationship. This signifies that owner or managers of SME need to encourage these strategies in running their enterprises to enhance market performance.

It is also quite important to note that managers or owners of SMEs in Delta State are less likely to take risk in order to earn market performance as the study reveals. This development is quite worrisome as risk taking ability will promote better innovativeness and compositeness in business practice and one way of doing it is to work in alliance with partners that help provide complimentary capabilities (Miles \& Parroch, 2004).

\section{Recommendations}

The findings obtained from the analysis of data gives room for making recommendation. These include:

i. In order for SMEs to be competitive and continuously serve the need of customers, they need to be pro-active and aggressive in designing strategies that will enhance market performance. 
International Journal of Small Business and Entrepreneurship Research

Vol.8, No.2, pp.43-58, April 2020

Published by ECRTD-UK

Print ISSN: 2053-5821(Print), Online ISSN: 2053-583X (Online)

ii. Owners and managers of SMEs have to practice innovation-oriented marketing action that will allow the firm to concentrate on new ideas that will lead to creation of new markets.

iii. SME owners and managers should also be able to discover unsatisfied needs and capture new opportunities in order to have better market performance. Being opportunity focus will help in innovation and creativeness which will make firms to have competitive advantage.

iv. It is quite pertinent for entrepreneurs to develop the resource leveraging so that they have the ability to recognize how an under-utilized resource could be used in other conventional way to enhance productiveness.

\section{Reference}

Ariyo, D. (2005). Small firms are the backbone of the Nigerian economy. Retrieved May 23, 2018, from http://www.africaeconomicanalysis.org

Ayyagari M.T; Beck and Demirgue - Kunt (2003). Small and medium enterprises across the globe. A new database. World Bank development research group working paper 3/27. Retrieved from www.academic.edu 14 May 2019.

Barry, T., \& Howard, D. (1990). A review and critique of the Hierarchy of effects in Advertising, International Journal of advertising, 2, (121): 18-24

Becherer, R. C., \& Maurer, J. G. (1997). The moderating effect of environmental variables on the entrepreneurial and marketing orientation of entrepreneur-led firms. Entrepreneurship theory and practice, 22, 47-58.

Becherer, R. C.; Helms, M. M.; and McDonald, J. P. (2012). The Effect of Entrepreneurial Marketing on Outcome Goals in SMEs. New England Journal of Entrepreneurship. 15(1)

Belch, M. (2009). Branding and consumer decision. Retrieved from

Ekpeyong David Nyang (1992). Small and medium scale enterprises in Nigeria. Their characteristic problem and sources of finance. African Economic Research consortium Nainebi

Entrepreneurial marketing: explore the strategy of entrepreneurial marketing. (2014) [www document]. [Accessed 21 may 2018]. http://www.marketing-schools.org/types-ofmarketing/entrepreneurial-marketing.html

Fiore, A.M. Nielm, L.S. Hurst, J.L. Son, J. \& Sudachar, A. (2013). Entreprenurial Marketing: Scale validation with small, independently owned business. Journal of Marketing Development and Competitiveness. 7(4) 63-86

Gliga, G. M. (2016). Entrepreneurial networking and the development of marketing capabilities in SMEs. A study of Irish entrepreneurs. http://hdl.handle.net/10379/6492

Hills, G. E., \& Hultman, C. (2013). Entrepreneurial Marketing: Conceptual and Empirical Research Opportunities. Entrepreneurship Research Journal, 3(4), 437-448.

Irina, V. K. Stephen, A. S. \& Robert, W. P. (2013). Resource-based theory in marketing. Journal ofthe Academic Marketing Science.

Janet, M. \& Ngugi, K. (2014). Influence of Entrepreneurial Marketing on the Growth of Smes In Kiambu Town-CBD, Kenya. European Journal of Business Management, 1 (11), 361-377.

John P. (2012) "the effect of entrepreneurial marketing on outcome goals in SMEs" New England Journal of Entrepreneurship: Vol. 15:No. 1, Article 3; Available at: http://digitalcomonons.sacredheart.edu/neje/vol15/iss/3 
International Journal of Small Business and Entrepreneurship Research

Vol.8, No.2, pp.43-58, April 2020

Published by ECRTD-UK

Print ISSN: 2053-5821(Print), Online ISSN: 2053-583X (Online)

Kotler, P \& Keller, L. K. (2012) Marketing Management. 14 edition. Pearson Education, Inc., publishing as Prentice Hall, One Lake Street, Upper Saddle River, New Jersey

Krohmer, H., Homburg, C., \& Workman, J., (2002) "Should Marketing be Cross-Functional? Conceptual Development and International Empirical Evidence", Journal of Business Research, Vol. 55, Accessed 17 May 2018.

Kurtz, D. (2010). Contemporary Marketing Mason, OH: South-Western Cengage Learning.

Mari, K. (2014). Planning And Implementation of Entrepreneurial Marketing Processes in SMEs. Lappeenranta University of Technology, School of Business, Master's Degree Program in International Marketing Management.

Mehran, R. \& Morteza, K. (2014). Evaluation of Entrepreneurial Marketing Dimensions According to Characteristics of Institutions: Institutions Age and Size. International Journal of Basic Sciences \& Applied Research. 3(4), 207-213. Available Online at http://www.isicenter.org

Mehran, R. and Morteza, K. (2013). Prioritization of entrepreneurial marketing dimensions: A case of in higher education Institutions by using entropy. Interdisciplinary Journal of Contemporary Research in Business. 4 (12); 297-306.

Mohammed (2011); Market Orientation and Business Performance among SMEs in Ghana: Journal of International Business Research Vol. 4 No. 1. January 2011 Retrieved from: www.ccsenet.rog/ibr

Morali, D. (2018). Hierarchy of Effect. Retrieved from

http://www.marketingsavant.com/2009/06/marketing-classics-the-hierarchy-of-effect

Morrish S.C., Miles, M.P. \& Deacon J.H (2010). Entrepreneurial Marketing: Acknowledging the entrepreneur and customer centric interrelationship. Journal of Strategic Marketing 18(4), 303-316

Mugambi, E. N. \& Winifred N. Karugu, W. N. (2017). Effect of Entrepreneurial Marketing on Performance of Real Estate Enterprises: A Case of Optiven Limited in Nairobi, Kenya. International Academic Journal of Innovation, Leadership and Entrepreneurship 2, (1) 26-45

Nunnally, J.C \& Bernstein I.H (1994). The assessment of Rehability \& Psychometric Theory. Retrieved from: https://www.scirp.org

Nwaizugbo, I. C and Anukam, A. I (2014). Assessment of Entrepreneurial Marketing Practices among Small and Medium Scale Enterprises in Imo State Nigeria: Prospects and Challenges. Review of Contemporary Business Research, 3(1). www.aripd.org/rcbr

Olaniyan, T., Ogbuanu, B, and Oduguwa, A. (2017). Effect of Entrepreneurial Marketing on SMEs Development in Nigeria. International Journal of Advanced Studies in Business Strategies and Management | IJASBSM 5(2) 46-60

Olannye, A.P and Eromafuru E. (2016). The Dimension of Entrepreneurial Marketing on the Performance of Fast Food Restaurants in Asaba, Delta State, Nigeria. Journal of Emerging Trends in Economics and Management Sciences (JETEMS) 7(3): 137-146

Oyelola, O. T., Ajiboshin, I. O. and Raimi, L. (2013). Entrepreneurship for Sustainable Economic Growth in Nigeria. Journal of Sustainable Development Studies, 2 (2) 197-215

Peteraf, M. \& Bergen, M. (2003). "Scanning dynamic competitive landscapes: a market-based and resource-based framework", Strategic Management Journal. 24; 1027-1041.

Pitsamon Kilenthong, Gerald E. Hills \& Claes M. Hultman (2015). Journal of International Marketing Strategy. Vol 3 No. 1 summer 2015 PP. 1- 18 mtml.us/img.kilenthong.pdf

Richard, L. P. \& John, E. B. (2001). Is The Resource-Based "View" A Useful Perspective For Strategic Management Research? Academy of Management Review. 26 (1), 22-40. 
Saifi (2016). 7 Ways to measure marketing performance. https://tech.co>7-waysmeasuremarketing-prormance

Smedan (2013). Survey report on Micro, small and medium enterprises in Nigeria. Nigerian bureau statistics and small and medium enterprises development agency of Nigeria.

Tooraj S., Masoomeh H. K., \& Seyed E. H. (2013). The investigation of Lavidge and Steiner model's capability in measuring the advertising effectiveness of fire insurance (Case study: Insurance company in Mashhad). European Online Journal of Natural and Social Sciences; 2(3); 1559-1567. www.european-science.com 